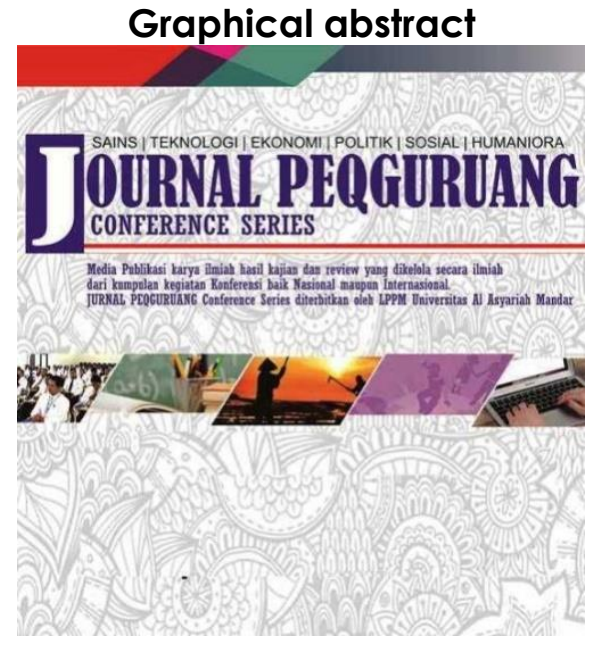

\title{
PENGARUH MODEL PEMBELAJARAN SSCS TERHADAP KEMAMPUAN PEMECAHAN MASALAH MATEMATIS SISWA SMP NEGERI 1 POLEWALI
}

\author{
${ }^{1}$ Asvin $*$, ${ }^{2}$ Chuduriah Sahabuddin, ${ }^{3}$ Muhammad Ali P \\ Program Studi Pendidikan Matematika \\ Fakultas Keguruan dan Ilmu Pendidikan \\ Universitas Al Asyariah Mandar
}

Corresponding email

asvin21091995@gmail.com

\begin{abstract}
This research is an experimental research with the aim to be able to measure the extent of the mathematical problem solving of eighth grade students of SMP Negeri 1 Polewali taught using the SSCS learning model. Simple Random Sampling is the method used for sample selection. Problem understanding tests and observation sheets are the instruments used in this study. Descriptive and inferential statistics are data analysis methods used in this study. According to the research results higher data obtained in the experimental class with a score of 82.38 and a standard deviation of 9.785. Whereas in the control class the score was 61.44 and the standard deviation was 13.77 . Then for inferential data it is found that both data are normal and the same value based on the data that has been obtained Ho is rejected and $\mathrm{H} 1$ is accepted because the significant value $<0.05$. So it can be concluded that there is an influence of the SSCS learning model on the mathematical problem solving ability of students of class VIII of SMP Negeri 1 Polewali.
\end{abstract}

Keywords: Influence; SSCS; Problem Solving Ability

\begin{abstract}
Abstrak
Penelitian ini merupakan penelitian eksperimen yang dengan maksud dapat mengukur sejauh mana penyelesaian masalah matematis siswa kelas VIII SMP Negeri 1 Polewali yang di ajar dengan menggunakan model pembelajaran SSCS. Simple Random Sampling adalah cara yang ditempuh untuk pemilihan sampel.tes pemahaman masalah dan lembar observasi merupakan instrument yang digunakan dalam penelitian ini. Statistic deskriptif dan inferensil merupakan cara analisis data yang digunakan dalam penelitian ini. Sesuai hasil penelitian data lebih tinggi didapat pada kelas eksperimen dengan skor sebesar 82,38 dan standar deviasi sebesar 9,785. Sedangkan pada kelas kontrol didapatkan skor 61,44 dan standar deviasi sebesar 13,77. Kemudian untuk data inferensial didapatkan bahwa kedua data bernilai normal dan sama berdasar pada data yang telah diperoleh $\mathrm{H}_{\mathrm{o}}$ ditolak dan $\mathrm{H}_{1}$ diterima karena nilai signifikan $<0,05$. Sehingga dapat ditarik kesimpulan terdapat pengaruh model pembelajaran SSCS terhadap kemampuan pemecahan masalah matematis siswa kelas VIII SMP Negeri 1 Polewali.
\end{abstract}

Kata kunci: Pengaruh; SSCS; Kemampuan Pemecahan Masalah

\section{Article history}

DOI: http://dx.doi.org/10.35329/ip.v2i2.1453

Received : 02 Agustus 2020 | Received in revised form : 23 September 2020 | Accepted : 27 Oktober 2020 


\section{PENDAHULUAN}

Dalam satuan sistem pendidikan komponen yang paling dibutuhkan adalah siswa. Pembelajaran tidak akan bisa terlaksana tanpa adanya siswa. Siswa merupakan bagian sistem pendidikan yang akan diproses dan dikembangkan sesuai dengan potensinya dalam satuan pendidikan. Oleh sebab itu, seorang guru harus mampu mengenali karakteer setiap siswanya, sehingga dalam pelaksanaan tujuan pembelajaran dapat tercapai. dalam satuan pendidikan yang merupkan hal yang dibutuhkan yakni pemahaman siswa dalam menyeleleasikan masalah yang diberikan. Sehingga lewat hasil yang diperoleh dapat terlihat sejauh mana kemampuan pemecahan masalah matematis siswa mengerjakan masalah yang diberikan. Pemecahan masalah menurut prasetiawan (23: 2016) yakni sebuah carak mendapatkan sebuah penyelesaian tertentu. Menurut Polya (dalam Wilis 2006:39) tahapan pemecahan masalah dibedalan menjadi empat bagian yanitu:

1. Memahami Masalah

Pada tahap ini ada beberapa langkah yang dapat dilalui siswa. memberikan pertanyaan mengenai apa yang diketahui dan dicari

a. Mampu menguasai dan membahasan materi dengan kalimat sendiri.

b. Siswa diharapkan bisa mengaitkan dengan masalah lain

c. Dapat konsentrasi pada inti dari masalah

2. Membuat rencana

Pada tahap ini siswa diharapkan mampu mempersiapkan rancangan penyelesaian yang diperlukan.

a. Memperkirakan

b. Megembangkan suatu bentuk

c. Menyederhanakan masalah

d. Mengidentifikasi pola

e. Membuat tabel

f. Bekerja terbaik

g. Kemungkinan semua diuji.

h. Dapat memahami sub tujuan

i. Data disusun

3. Melaksanankan rencana

Siswa dapat menyelesaikan tugas yang diberikan sesuai dengan rencana sebelumya.
a. Mampu memodelkan dalam bentuk matematika
b. Strategi dilaksanakan.

4. Melihat kembali

Setelah penyelesaian tugas yang diberikan terdapat langka-langkah yang dapat dilalui siswa.

a. Semua data diperiksa ulang

b. Perhitungan diperiksa kembali

c. Sulusi yang di dapatkan dipikirkan ulang

d. Mencari cara lain
Dalam penyelesaian sebuah masalah matematis hendaknya siswa dapat menerapkan setiap indikator dalam pemecahan masalah. Sehingga pembelajaran lebih menyenangkan bagis siswa. Kemampuan siswa dalam pembelajaran itu dilihat dari hasil belajar siswa itu sendiri (Sahabuddin 2016: 18). Selain itu, dalam proses pembelajaran guru juga diharapkan mampu menyampaikan pembelajaran sesuai dengan indikator dan tujuan pemeblajaran yang diajarkan. Untuk itu guru dituntut untuk dapat mendesain kegiatan pembelajaran sedemikian rupa sehingga pembelajaran bisa menyenangkan dan bisa dipaha,I oleh siswa dengan baik. Pemahaman siswa siswa dalam mempelajarai materi pelajaran matematika itu dilihat dipengaruhi dari desain model pembelajaran yang diterapkan oleh guru mate pelajaran (Febryanti 2019: 14).

Menurut Ali P dkk (2016) pemilihan bentuk pelajaran yang tepat itu akan sangat berpengaruh pada hasil belajar siswa. Setiap model yang dipilih tentunya memiliki karekteristik yang berbeda-beda.

Jadi bentuk pelajaran yang pilih diupayakan mampu membantu murid dalam pembelajaran matematika sehingga mampu memberdayakan siswa atau dalam artian bahwa siswa yang lebih aktif dalam palaksanaan belajar mengajar. Bentuk pembelajaran SSCS merupakan salah satu bentuk pembelajaran yang sesuai yang diyakini mampu menaikan pemahaman siswa dalam menyelesaikan masalah.

Menurut Pizzini (dalam Sari, 09: 2018) bentuk pembelajaran SSCS ini memiliki empat fase yang pertama mengidentifikasi masalah (fase Search), merencanakan dan melaksanakan penyelesaian masalah (fase Solve), menuliskan solusi masalah yang diperoleh (fase Create), mensosialisasikan solusi masalah (fase Share). Bentuk pembelajaran ini bisa di pilih setiap tenaga pendidik mata pelajaran matematika untuk melaksanakan kegiatan pengajaran. Bentuk pembelajaran ini juga sangat mudah diterapakan karena memiliki langka pembelajaran yang sederhana.

Berdasarkan keunggulan mengenai model pembelajaran SSCS, peneliti mempunyai soslusi dengan mengajukan sebuah penelitian dengan judul "pengaruh model SSCS terhadap kemampuan pemecahan masalah matematis siswa SMP Negeri 1 Polewali“.

\section{METODE PENELITIAN}

Jenis penelitian yang dipakai adalah pekperimen. Pelaksanaannya dilakukan di SMP Negeri 1 Polewali yang berlokasi di Jl. Hj. Andi Depu No.82, Lantora, Polewali, Kabupaten Polewali Mandar, Sulawesi Barat. 
Dalam menentukan sampel dilakukan dengan cara teknik sampling atau pemilihan secara acak

Adapun Sampel penlitian yakni siswa VIII E dan kelas VIII G. satu kelas sebagai kelas eksperimen, yaitu kelas VIII E yang mendapat perlakuan pembelajaran SSCS, sedangkan pada kelas kontrol yaitu kelas VIII G yang memakai bentuk belajar biasa. adalah:

Adapun desain penelitian yang digunakan

Tabel 1. Desain penelitian pre test dan post test control grup design.

\begin{tabular}{|c|c|c|c|}
\hline $\mathrm{E}$ & $\mathrm{O}_{1}$ & $\mathrm{X}$ & $\mathrm{O}_{3}$ \\
\hline $\mathrm{K}$ & $\mathrm{O}_{2}$ & - & $\mathrm{O}_{4}$ \\
\hline
\end{tabular}

Sumber: (Dantes 2012: 102)

Cara perampunagn data yang dipakai yaitu melalui tes kemampuan pemecahan masalah dan lembar observasi. Tes yang diberikan menggunakan bentuk cerita dengan soal cerita diharapakan bisa menjawab secara sistematis sehinga cara pemikiran siswa dapat terbentuk, (Suherman, 2003) dan juga untuk mengetahui bagaiaman siswa menuangakan pemikirannya secara tertulis. Kemampuan hasil pemecahan masalah dievaluasi dan menelaah hasil tes akhir siswa.

Terdapat dua jenis perhitugan yang dipakai statistik, deskriptif, dan statistic inferensial. Namun sebelum melakukan uji hipotesis hal yang harus dilakuakan adalalah melakukan uji prasyarat.

\section{HASIL DAN PEMBAHASAN}

Analisis deskriptif digunakan untuk mengetahui keadaan awal siswa yang akan diteliti. Rangkuman hasil deskriptif disajikan pada tabel 2.

Tabel 2. Rekapitulasi hasil perhitungan kemampuan pemecahan masalah matematis.

\begin{tabular}{|c|c|c|c|c|}
\hline & \multicolumn{2}{|c|}{ Pre test } & \multicolumn{2}{c|}{ Post test } \\
\hline Kelas & $\mathrm{E}$ & $\mathrm{K}$ & $\mathrm{E}$ & $\mathrm{K}$ \\
\hline Mean & 30.758 & 29.524 & 82.380 & 61.442 \\
\hline Median & 34.400 & 31.100 & 83.10 & 63.100 \\
\hline Mode & 48.20 & 24.10 & 95.30 & 75.30 \\
\hline St.deviation & 15.587 & 12.8240 & 9.7858 & 13.7766 \\
\hline Min & 00 & 10.30 & 60.00 & 30.70 \\
\hline Max & 48.20 & 58.60 & 95.30 & 80.00 \\
\hline
\end{tabular}

Sumber: Data hasil analisis deskriptif

Berdasarkan hasil perhitungan statistic deskriptif dari tabel Tabel 2 maka bisa ditarik kesimpulan bahwa kedua kelas memiliki perbedaan yang sangat jauh. Ini dibuktikan dengan selisih interval nilai yang diperoleh siswa pada kedua kelas yang menunjukkan bahwa interval nilai pada kelas eksperimen itu lebih besar dari pada kelas kontrol.
Berdasarkan hasil observasi keterlaksanaan model didapatkan hasil persentase keterlaksanaan model pada hari pertama $75 \%$, pada hari ke dua 95,8\% dan pada hari ketiga diperoleh persentase 100\%. Maka diperoleh rata-rata persentase 90,2\% berdasarkan hasil ini maka dapat ditarik kesimpulan bahwa bentuk pembelajaran yang diterapkan terlaksana dengan maksimal

Kemudian untuk hasil observasi siswa itu dapat dilihat pada tabel berikut.

Tabel 3. Data hasil observasi aktivitas siswa

\begin{tabular}{|c|c|c|c|c|c|}
\hline \multirow{2}{*}{ No } & \multirow{2}{*}{ Kelas } & \multicolumn{3}{|c|}{ Pertemuan } & \multirow{2}{*}{ Persentase } \\
\hline & & 1 & 2 & 3 & \\
\hline 1 & Eksperimen & $\begin{array}{c}81,8 \\
\%\end{array}$ & $\begin{array}{c}95,4 \\
\%\end{array}$ & $\begin{array}{c}95,8 \\
\%\end{array}$ & $91 \%$ \\
\hline 2 & Kontrol & $\begin{array}{c}84,1 \\
\%\end{array}$ & $\begin{array}{c}90,9 \\
\%\end{array}$ & $\begin{array}{c}93,3 \\
\%\end{array}$ & $89,4 \%$ \\
\hline
\end{tabular}

Sumber: hasil olahan data observasi

Statistik inferensial digunakan untuk pengujian hipotesis dengan taraf kesalahan terkecil $\alpha=0,05$. Namun sebelum itu dilakukan lebih dulu harus dilakuakn uji normalitas dan uji homogenitas

Berdasarkan hasil perhitungan yang telah dilaksanakan didapatkan nilai signifikan 0,134 pada kelas eksperimen dan pada kelas kontrol didapatkan nilai signifikan 0,62. Berdasar pada data yang telah didapatkan dapat ditarik suatu kesimpulan bahwa sampel penelitian bernilai normal karena kedua nilai signifikan lebih tinggidari 0,05. Kemudian pada hasil analisis homogenitas pada kedua kelas didapatkan nilai signifikan sebesar 0,82. Ini membuktikan bahwa kedua kelas sama atau homogen.

Pada saat didapatkan bahwa kedua kelas layak yaitu kedua kelas siarat untuk diteliti maka selanjutnyan dilakukan uji hipotesis dengan uji-t. dikatakan $\mathrm{H}_{\mathrm{o}}$ ditolak jika thitung $>t_{\text {tabel }}$ dan terima $\mathrm{H}_{\mathrm{o}}$ jika thitung $<$ tabel.

Berdasarkan perhitungan data dengan menggunakan uji-t diketahui thitung 6,969 dan $t_{\text {tabel }}$ 1,999 dari perhitungan ini didapatkan bahwa thitung lebih besar dari $t_{\text {tabel. }}$ Berdasar pada hasil perhitungan ini maka dapat disimpulakan bahwa $\mathrm{H}_{\mathrm{o}}$ ditolak dan $\mathrm{H}_{1}$ diterima.

Hasil dari perhitungan ini dapat dilihat ada perbedaan hasil penyelesaian pemecahan masalah mamtematis secara signifikan dari kedua kelas. ini terjadi karena adanya pengaruh perlakuan yang dilakuakn berbeda. Untuk keles eksperimen siswa belajar denganbentuk belajar SSCS dimana siswa ditantang untuk mengkonstruksi cara belajar sendiri dengan tahapan-tahapan bentuk proses belajar yang dilakukan. Hal ini akan menyebabkan proses belajar lebih menyenangkan dan antusias siswa benar-benar terlihat dalam pelaksanaan pembelajaran. Selain itu dalam penggunaan model SSCS ini sangat menekankan untuk menggunakan LKS dalam proses pembelajran. LKS ini dibagikan pada setiap kelompok yang didalamnya berhubungan dengan 
soal cerita yang bercerita tentang kehidupan nyata. Sehingga dengan LKS ini siswa lebih antusias dalam menyelesaikan masalah yang diberikan. Dengan demikian hasil pemikiran dan kemampuan pemecahan masalah siswa akan meningkat dan tujuan pelajaran pun juga akan tercapi sesuai indictor pencapaian.

Sedangkan untuk kelas kontrol pembelajaran dilaksanakan dengan model konvensional dengan metode ceramah dan bentuk pengasan dalam bentuk latihan. Kemudian guru dalam proses pembelajran juga jarang mengaitakn materi pelajaran dengan kehidupan nyata sehingga pengetahuan siswa sangat terbatas dalam mengkaji materi pelajaran yang diberikan. Sehingga hal ini akan mempengaruhi kemampuan pemecahan masalah siswa itu sendiri.

Berdasarkan uraian terdahulu maka dapat disimpulkan bahwa penelitian yang telah dilakukan ini bisa menjawab masalah dari penelitian ini sebagaiman yang telah dirumuskan pada rumusn masalah.”

\section{SIMPULAN}

Dengan melihat hasil analisis dekriptif dan hasil analisis inferensial yang telah dilakuan. Dimana pada hasil analisis deskriptif diperoleh selisih intervasl nilai dari kedua kelas lebih diatas pada kelas eksperimen. Kemudian berdasar padahasil analisis inverensial didapatkan nilai thitung lebih besar dari ttabel yaitu thitung 6,969 > tabel 1,999. Maka dapat ditarik kesimpulan ada pengaruh penggunaan model pembelajaran search, solve, create and share (SSCS) terhadap kemampuan pemecahan masalah Matematis siswa kelas VIII SMPN 1 Polewali.

\section{DAFTAR PUSTAKA}

Dantes, Nyoman. 2012. Metode Penelitian. Yogyakarta: C.V Andi Offset

Febryanti, F. 2019. Efektifitas Metode Pembelajaran Examples Non Examples Terhadap Hasil Belajar Matematika. In Journal Peqguruang: Conference Series. Vol. 1, No 2, pp.168-173)

Prasetiawan, Agung. 2016.Peningkatan Hasil Belajar Matematika Melalui Penerapan Teori Belajar Polya Materi Sistem Persamaan Linear Dua Variabel Peserta Didik Kelas VIII SMP Negeri 5 Wono: Skripsi Unasman, Tidak di publikasikan

Rahmawati, N. T., Junaedi, I., \& Kurniasih, A. W. (2013). Keefektifan Model Pembelajaran SSCS Berbantuan Kartu Masalah terhadap Kemampuan Pemecahan Masalah Siswa.
Unnes Journal of Mathematics Education, 2(3).

Sahabuddin, C. (2016). Hubungan Komunikasi Belajar Mengajar Terhadap Hasil Belajar Peserta Didik Di Sekolah Menengah Kejuruan Negeri 1 Kabupaten Majene. Pepetudzu: Media Pendidikan Dan Sosial Kemasyarakatan, 10(1), 17-30.

Sari, Desi Ratna. 2018. Pengaruh Penerapan Model Pembelajaran SSCS Terhadap Pemahaman Konsep Matematis. Riau: UINSSKR.

Suherman, E. (2008). Model Belajar Dan Pembelajaran Berorientasi Kompetensi Siswa. Educare, $5(2)$.

Upu,H., \& Djadir, D. (2016). Pengembangan Perangkat Pembelajaran Matematika Model Koperatif Tipe Student Teams Achievement Division (STAD) Dengan Pendekatan Saintifik.Pepatudzu: Media Pendidikan Dan Sosial Kemasyarakatan, 9(1), 16-28. 